\title{
The Influence of Anselm of Canterbury on the Summa Halensis' Theology of the Divine Substance
}

\begin{abstract}
The influence of Anselm of Canterbury can be found in all four parts of the Summa Halensis. It is true that among the hundreds of quotations of Anselm, the majority occur in the third part, on Christology, but the Franciscan authors of the Summa also found Anselm to be very useful in the first part, as well. The authors of the Summa drew especially from Anselm's Monologion and Proslogion when discussing God as the divine substance. After examining how infrequently scholastic theologians in the generation before the Summa appropriated Anselm in their discussions of God's existence and attributes, the essay demonstrates that the authors of the Summa engaged Anselm on a much more sustained level and drew from a much wider variety of Anselmian sources than did their predecessors.
\end{abstract}

The theology of Anselm of Canterbury, after an uneven reception in the $12^{\text {th }}$ century, exerted considerable influence on early Franciscan theologians in the first half of the $13^{\text {th }}$ century. ${ }^{1}$ Anselm's prayerful reflections on God's attributes and existence in the Proslogion, the Trinitarian Persons in the Monologion, and his Christology and soteriology in the Cur Deus Homo resonated with such authors as Alexander of Hales, John of La Rochelle, Odo Rigaldus, William of Melitona, and Bonaventure of Bagnoregio, some, or all, of whom contributed either directly or indirectly to the compilation of the Summa Halensis. ${ }^{2}$ Scholars have noted the role Anselm's thought has played in the areas of early Franciscan arguments for God's existence, ${ }^{3}$ Trinitarian theology, ${ }^{4}$

\footnotetext{
1 See Enzo Marigliano, Anselmo d'Aosta: La vicenda umana di un grande monaco del Medioevo (Milano: Ancora, 2003), 229.

2 See Victorin Doucet, 'Prolegomena in librum III necnon in libros I et II "Summa Fratris Alexandri”, , in Doctoris irrefragabilis Alexandri de Hales Ordinis minorum Summa theologica, vol. 4 (Quaracchi: Collegium S. Bonaventurae, 1948), cxxxIV-CCXLVII.

3 See Scott Matthews, 'Arguments, Texts, and Contexts: Anselm's Argument and the Friars,' Medieval Philosophy and Theology 8 (1999): $83-104$ and Scott Matthews, Reason, Community and Religious Tradition: Anselm's argument and the Friars (Aldershot: Ashgate, 2001), 35-9, 50-73, 111-43; and Rega Wood, 'Richard Rufus's Response to Anselm,' in Anselm and Abelard: Investigations and Juxtapositions, ed. G.E.M. Gasper and H. Kohlenberger (Toronto: Pontifical Institute of Mediaeval Studies, 2004), 87-102.

4 See Matthew Levering, 'Speaking the Trinity: Anselm and His $13^{\text {th }}$-Century Interlocutors on Divine Intelligere and Dicere,' in Saint Anselm-His Origins and Influence, ed. John R. Fortin (Lewiston, NY: The Edward Mellen Press, 2001), 131- 43.
} 
soteriology, ${ }^{5}$ and Christology. ${ }^{6}$ Focusing on the theology of Alexander of Hales, Aleksander Horowski has noted that, in his Gloss on Peter Lombard's Sentences and disputed questions, Alexander cites Anselm 314 times, especially in discussions of free will and Christology. ${ }^{7}$

It is no surprise, then, that Anselm's theology is a significant source in the Summa Halensis. In fact, not only does Anselm's theology play an even more significant role in the Summa than it does in Alexander's Gloss on the Sentences, but it also influences discussions on a wider variety of topics than those that scholars have recently examined. The Quaracchi editors, in their index of cited authorities, noted over 500 direct references to Anselm in Books 1 to 3 (and there are many more if one both includes Book 4 and adds Eadmer of Canterbury's Liber de similitudinibus to the list of Anselmian material). ${ }^{8}$ This quantity approximates or exceeds the number of references in the Summa to the works of such authors as Ambrose of Milan, Bede, John of Damascus, and Bernard of Clairvaux.

Although the Summa draws much inspiration from Anselm's Cur Deus homo in its Christology and soteriology, this essay will examine another theological subject on which Anselm's theological and philosophical insight was brought to bear, namely God's existence and attributes. Of course, the Proslogion plays a role here, but the Summa draws from a wide variety of Anselmian texts to explicate how God's attributes should be understood. When one juxtaposes how the Summa treats God's existence and attributes with how earlier theological texts do so, one notices that the discussion of what the Summa calls the divine substance not only contains many more

5 See Hubert Philipp Weber, Sünde und Gnade bei Alexander von Hales: Ein Beitrag zur Entwicklung der theologischen Anthropologie im Mittelalter (Innsbruck/Wien: Tyrolia Verlag, 2003), 100, 162, 363-4, 378-9; and Robert Pouchet, La rectitudo chez saint Anselme: Un itinéraire augustinien de l'ame à Dieu (Paris: Études Augustiniennes, 1964), 252-9.

6 See Walter H. Principe, The Theology of the Hypostatic Union in the Early Thirteenth Century, vol. 2, Alexander of Hales' Theology of the Hypostatic Union (Toronto: Pontifical Institute of Mediaeval Studies, 1967), 41, 116-7, 184-8, 196-8; Michael Robson, 'Saint Anselm, Robert Grosseteste and the Franciscan Tradition,' in Robert Grosseteste: New Perspectives on His Thought and Scholarship, ed. James McEvoy (Turnhout: Brepols, 1995), 233-56; Michael Robson, 'The Impact of the Cur deus homo on the Early Franciscan School,' in Anselm: Aosta, Bec, and Canterbury: Papers in Commemoration of the Nine-Hundredth Anniversary of Anselm's Enthronement as Archbishop, 25 September 1093, ed. D.E. Luscombe and G.R. Evans (Sheffield: Sheffield Academic Press, 1996), 334-47; Michael Robson, 'Anselm's Influence on the Soteriology of Alexander of Hales: The Cur Deus homo in the Commentary on the Sentences,' in Cur Deus Homo: Atti del Congresso Anselmiano Internazionale, Roma 21-23 maggio 1998, ed. Paul Gilbert, Helmut Kohlenberger, and Elmar Salmann (Rome: Pontificio Ateneo S. Anselmo, 1999), 191-219; and Michael Robson, 'Odo Rigaldi and the Assimilation of St Anselm's Cur Deus homo in the School of the Cordeliers in Paris,' in Saint Anselm of Canterbury and His Legacy, ed. Giles E.M. Gasper and Ian Logan (Durham: Institute of Medieval and Renaissance Studies; Toronto: Pontifical Institute of Mediaeval Studies, 2012), 155-73.

7 Aleksander Horowski, La Visio Dei come forma della conoscenza umana in Alessandro di Hales (Roma: Istituto Storico dei Cappuccini, 2005), 16.

8 See Doucet, 'Prolegomena,' xcI. 
topics, but it also treats Anselm as a weightier authority and relies on Anselm much more than did earlier theological treatises.

\section{Anselm in the Parisian Theology of the 1220s}

Before the authors of the Summa appropriated Anselm extensively for their discussion of what they call the divine substance, previous Parisian theologians had barely mentioned Anselm. When considering God's existence, Peter Lombard in his Four Books of Sentences, drew principally upon Augustine. ${ }^{9}$ Alexander of Hales, in his Gloss on the Sentences, also included texts from John of Damascus, Pseudo-Dionysius, and Aristotle, ${ }^{10}$ while William of Auvergne engaged arguments from Boethius and Avicenna. ${ }^{11}$ William's treatise De Trinitate, written around 1223 as part of the larger Magisterium divinale, bears little trace of Anselm on the topic of divine substance. Philip the Chancellor, when explicating the highest Good in his Summa de bono, described it as that than which a greater cannot be thought, but other facets of Anselm's arguments are neglected..$^{12}$ Of these authors, however, only Alexander mentioned Anselm by name, once when maintaining that God cannot be thought not to exist and once when discussing the 'nothing' from which God created all things. ${ }^{13}$

Of any author writing in the 1220s, whose arguments influenced the Summa Halensis, William of Auxerre is the one who relied on Anselm the most when discussing God's existence and attributes. ${ }^{14}$ William's Summa aurea mentions Anselm by name in its listing arguments for God's existence. Drawing on Chapter 3 of the Proslogion, William explains the contention that God cannot be thought not to exist. ${ }^{15}$ Although Anselm's argument is the last of four arguments about God's existence, coming after causal arguments from Nicholas of Amiens and John of Damascus and after Boethius' concept of the best as the highest good, William's engagement with Anselm consists of much more than an appropriation of the Proslogion regarding God's exis-

\footnotetext{
9 See Peter Lombard, Sententiae in IV libris distinctae I, d. 3, c. 1, 2 vols, ed. Ignatius C. Brady (Grottaferrata: Editiones Collegii S. Bonaventurae, 1971-81), 1:68-71.

10 See Alexander of Hales, Magistri Alexandri Glossa in quatuor libros Sententiarum Petri Lombardi (hereafter, Glossa) I, dd. 2-3, 4 vols (Quaracchi: Collegium S. Bonaventurae, 1951-7), 1:27-74.

11 See William of Auvergne, De trinitate: An Edition of the Latin Text with an Introduction, cc. 1-5, ed. Bruno Switalski (Toronto: Pontifical Institute of Mediaeval Studies, 1976), 16-34.

12 Philip the Chancellor, Summa de bono, 2 vols, ed. Nicolaus Wicki (Berne: Francke, 1985), 1:46.

13 See Alexander of Hales, Glossa I, d. 3, 1:42, 70.

14 On William's influence within the larger context of the University of Paris, see Spencer E. Young, Scholarly Community at the Early University of Paris: Theologians, Education and Society, 1215-1248 (Cambridge: Cambridge University Press, 2014), 102-30.

15 William of Auxerre, Summa aurea I, tr. 1, 7 vols, ed. Jean Ribaillier, Spicilegium Bonaventurianum, 16-20 (Paris: Centre National de la Recherche Scientifique; Grottaferrata: Editiones Collegii S. Bonaventurae, $1980-7)$, 1:23.
} 
tence. William also relies on Anselmian texts to show that God is simple, ${ }^{16}$ true, ${ }^{17}$ omnipresent, ${ }^{18}$ merciful, and just. ${ }^{19}$ Given the repeated mention of Anselm's name, in contradistinction to the usage in other roughly contemporaneous theological texts, and the appropriation of his arguments, William's reliance on Anselm as a theological authority, even if not at all widespread, is significant.

\section{Anselm in the Summa's Theology of the Divine Substance}

Even if William of Auxerre had found Anselm to be a helpful theological resource, there are only five explicit references to Anselm in the first book of the Summa aurea regarding God's existence and attributes. ${ }^{20}$ Compared to the omission of Anselm from roughly contemporaneous texts, the Summa aurea represents a retrieval of several important Anselmian theological insights, but the overall influence of Anselm on the theology of God's existence and attributes in the 1220s is negligible, and it is in this regard that the Summa Halensis makes several notable contributions.

After the paucity of references to Anselm in the preceding generation, the Summa Halensis appropriates numerous Anselmian texts when discussing the same topics. Anselm first appears in the Summa in the opening question of the first part of Book $1,{ }^{21}$ which explains the 'unity of the Trinity ordered towards the belief of the heart'.22 The first question of that section, on the 'essentiality of the divine substance', addresses God's existence. ${ }^{23}$ The Summa gives five reasons for why God must exist, and three are derived from Anselm. The first argument is from Richard of St Victor's De Trinitate and argues that things that begin in time must have their being from another; since all created things draw their existence from some-

16 Regarding God's simplicity, William makes two Anselmian arguments without citing Anselm explicitly. First, William argues that God is a maximum who does not owe His existence to another; and secondly, good things predicated of God are the same in God (see William of Auxerre, Summa aurea I, tr. 2 (Ribaillier, 1:24)).

17 William of Auxerre, Summa aurea I, tr. 12, c. 4, q. 8 (Ribaillier, 1:242).

18 William of Auxerre, Summa aurea I, tr. 14, c. 1 (Ribaillier, 1:262).

19 William of Auxerre, Summa aurea I, tr. 13, c.1 (Ribaillier, 1:246-7).

20 There are, however, a few other implicit references, and there is one explicit reference to Anselm regarding the procession of the Holy Spirit.

21 Alexander of Hales, Doctoris irrefragabilis Alexandri de Hales Ordinis minorum Summa theologica (SH), 4 vols, (Quaracchi: Collegium S. Bonaventurae, 1924-48), Vol I, P1, In1, Tr1, Q1, C1 (n. 25 ), p. 41. 22 SH I, P1, In1, prol., p. 39: 'Est igitur inquisitio bipartita de Unitate et Trinitate deitatis: prima de ipsa re, quae est Unitas Trinitatis ordinata ad credulitatem cordis; secunda de nominatione ordinata ad confessionem oris, ut sciamus quod credimus, confiteri locutionibus catholicis et veris.'

23 SH I, P1, In1, Tr1, Q1, p. 40: 'De divinae igitur substantiae essentialitate ostendenda sunt duo: primo, quod necesse est divinam substantiam esse; secundo, quod necesse est notam esse sic ut non possit cogitari non esse.' 
thing else, there must be an eternal being that has being (esse) from itself. The Summa then cites John of Damascus as proving the existence of the divine substance according to the notion of causality. Quoting from Book 1 of On the Orthodox Faith, the authors of the Summa note that since created substances are causable, there must an 'incausable substance' that causes all other substances. ${ }^{24}$

The remaining three arguments all incorporate important passages from Anselm. The authors of the Summa, in the first of these arguments, begin with the notion of truth. They quote from the opening of Anselm's De veritate, which in turn quotes two consecutive passages from the Monologion:

Let anyone who can, try to conceive of when it began to be true, or was ever not true, that something was going to exist. Or [let him try to conceive of] when it will cease being true and will not be true that something has existed in the past. Now, if neither of these things can be conceived, and if both statements can be true only if there is truth, then it is impossible even to think that truth has a beginning or an end. ${ }^{25}$

The Summa notes that 'we call this [eternal truth] the divine essence,26 and continues again with the opening of De veritate:

Indeed, suppose that truth had had a beginning, or suppose that it would at some time come to an end: then even before truth had begun to be, it would have been true that there was no truth; and even after truth had come to an end, it would still be true that there would be no truth. But it could not be true without truth. Hence, there would have been truth before truth came to be, and there would still be truth after truth had ceased to be. But these conclusions are self-contradictory. Therefore, whether truth is said to have a beginning or an end, or whether it is understood not to have a beginning or an end, truth cannot be confined by any beginning or end. ${ }^{27}$

24 SH I, P1, In1, Tr1, Q1, C1 (n. 25), p. 41: 'Cum ergo omnes substantiae huius mundi sint vertibiles, exierunt de non esse in esse; ergo causabiles; sed nihil est causabile a se; relinquitur ergo quod est substantia incausabilis, a qua sunt alia causabilia.'

25 Anselm of Canterbury, De veritate, c. 1, in S. Anselmi cantuariensis archiepiscopi Opera omnia, 6 vols, ed. F.S. Schmitt (Edinburgh: Thomas Nelson, 1946-61), 1:176: 'Cogitet qui potest, quando incepit aut quando non fuit hoc verum: scilicet quia futurum erat aliquid; aut quando desinet et non erit hoc verum: videlicet quia praeteritum erit aliquid. Quodsi neutrum horum cogitari potest, et utrumque hoc verum sine veritate esse non potest: impossibile est vel cogitare, quod veritas principium aut finem habeat.' All translations of Anselm's works are from Anselm of Canterbury, Complete Philosophical and Theological Treatises of Anselm of Canterbury, trans. Jasper Hopkins and Herbert Richardson (Minneapolis: The Arthur J. Banning Press, 2000), 164.

26 SH I, P1, In1, Tr1, Q1, C1 (n. 25), p. 41: 'Ergo est veritas aeterna: et hanc dicimus divinam essentiam.'

27 Anselm of Canterbury, De veritate, c. 1 (Hopkins and Richardson, 164-5; Schmitt, 1:176): 'Denique si veritas habuit principium aut habebit finem: antequam ipsa inciperet, verum erat tunc quia non erat veritas; et postquam finita erit, verum erit tunc quia non erit veritas. Atqui verum non potest esse sine veritate. Erat igitur veritas, antequam esset veritas; et erit veritas, postquam finita erit veritas; quod inconvenientissimum est. Sive igitur dicatur veritas habere, sive intelligatur non habere principium vel finem: nullo claudi potest veritas principio vel fine.' 
After concluding from these passages of Anselm that truth must exist eternally, the authors of the Summa discuss the distinction between something true secundum quid and something true simpliciter. They seem to concede as true secundum quid Augustine's argument from the Soliloquies that asserting that truth does not exist is a contradiction, since it would then be true that truth does not exist. While such a concession seems to undermine the conviction that truth exists eternally, since a true statement secundum quid requires some qualification, nonetheless the Summa goes on to state that 'everything true secundum quid is simpliciter from another perspective; if, therefore, there is something true secundum quid, it follows necessarily that something is true simpliciter and that there is some truth simpliciter. ${ }^{28}$

The fourth reason that shows God's existence is drawn from the notion of goodness. What is good in potency is less than what is good in act; likewise, what is good or best in the intellect is less than what is good or best in act. Drawing on the argumentation of Anselm in Chapter 2 of the Proslogion, the authors of the Summa contend that if the best were only in the intellect, there could be a better, namely a best that is both in the intellect and outside the intellect 'in a necessary act'. ${ }^{29}$ The best is explicitly linked with Anselm's phrase 'that than which none greater can be thought' so that 'if, therefore, no intellect can deny that the best is the best, it must concede necessarily that the best is in act. ${ }^{30}$

The fifth reason is from the notion of preeminence, a kind of argument from gradation. Although the Summa draws from an argument about gradations from Richard of St Victor's De Trinitate, ${ }^{31}$ it first uses an argument from the Monologion. In Chapter 4 of that work, Anselm says,

[A]lthough we cannot deny that some natures are better than others, nonetheless reason persuades us that one of them is so pre-eminent that no other nature is superior to it. For if such a division of gradation were so limitless that for each higher grade a still higher grade could be found, then reason would be led to the conclusion that the number of these natures is boundless. But everyone holds this [conclusion] to be absurd, except someone who himself is utterly irrational. ${ }^{32}$

28 SH I, P1, In1, Tr1, Q1, C1 (n. 25), p. 42: 'Si dicatur quod 'veritatem non esse, esse verum' ponit verum secundum quid, non simpliciter, tamen adhuc sequitur: quia omne 'secundum quid' est respectu alicuius quod est simpliciter; si ergo est verum secundum quid, sequitur necessario quod aliquid est verum simpliciter et aliqua veritas simpliciter.'

29 SH I, P1, In1, Tr1, Q1, C1 (n. 25), p. 42: 'In intellectu eius quod est 'optimum' intelligitur ens actu necessario: quia intellectus eius quod est 'optimum' est 'quo nihil est melius'.'

30 SH I, P1, In1, Tr1, Q1, C1 (n. 25), p. 42: 'Si ergo ens 'quo nihil melius' ponit ens actu necessario, ergo et optimum ponit ens actu; si ergo nullus intellectus potest negare optimum esse optimum, ergo necessario habet concedere optimum esse actu.'

31 See Richard of St Victor, De Trinitate I, c. 11, in De Trinitate: texte critique avec introduction, notes et tables, ed. Jean Ribaillier (Paris: Vrin, 1958), 95-6.

32 Anselm of Canterbury, Monologion, c. 4, in S. Anselmi cantuariensis archiepiscopi Opera omnia, 1:17 (Hopkins and Richardson, 11): 'Cum igitur naturarum aliae aliis negari non possint meliores, nihilominus persuadet ratio aliquam in eis sic supereminere, ut non habeat se superiorem. Si enim 
From this passage, the authors of the Summa affirm that there must be a supreme nature compared to which all finite natures are inferior.

In these arguments for the necessity of God's existence the Summa relies extensively on Anselm. While it is true that the authors of the Summa are content primarily to quote Anselm without offering much commentary-indeed, in the last three arguments, Anselm is given more space than the authors allow themselves-nonetheless the authors of the Summa have extracted important passages from De veritate, the Monologion, and the Proslogion and cast them in terms of ways of thinking about the divine essence.

The second chapter of Question 1 argues not only that God exists, but it also contends both that God cannot be thought not to exist and that only God cannot be thought not to exist. Although John of Damascus and Boethius are cited as authorities in these questions, Anselm's arguments play a much more important role. For example, a passage from Chapter 3 of the Proslogion is the first argument the Summa uses to demonstrate the God cannot be thought not to exist.

For there can be thought to exist something which cannot be thought not to exist; and this thing is greater than that which can be thought not to exist. Therefore, if that than which a greater cannot be thought could be thought not to exist, then that than which a greater cannot be thought would not be that than which a greater cannot be thought-[a consequence] which is contradictory. Hence, something than which a greater cannot be thought exists so truly that it cannot even be thought not to exist. And You are this [being], O Lord our God. ( ... ) For if any mind could think of something better than You, the creature would rise above the Creator and would sit in judgment over the Creator-something which is utterly absurd..$^{33}$

The authors of the Summa feel compelled to address the objection from Gaunilo that one could in fact think that there is no God, but all they provide as a response is Anselm's argument from Chapter 4 of the Proslogion that anyone who understands that God is that being than which none greater can be thought cannot think of God as not existing, since then a greater could be thought.

In addition to drawing extensively on Anselm's arguments for God's existence, the authors also find numerous passages in Anselm's works important for their discussion of God's other attributes. These attributes include God being infinite, uncir-

huiusmodi graduum distinctio sic est infinita, ut nullus ibi sit gradus superior quo superior alius non inveniatur, ad hoc ratio deducitur, ut ipsarum multitudo naturarum nullo fine claudatur. Hoc autem nemo non putat absurdum, nisi qui nimis est absurdus.'

33 Anselm of Canterbury, Proslogion, c. 3, in S. Anselmi cantuariensis archiepiscopi Opera omnia, 1:102-3 (Hopkins and Richardson, 94): 'Nam potest cogitari esse aliquid, quod non possit cogitari non esse; quod maius est quam quod non esse cogitari potest. Quare si id quo maius nequit cogitari, potest cogitari non esse: id ipsum quo maius cogitari nequit, non est id quo maius cogitari nequit; quod convenire non potest. Sic ergo vere est aliquid quo maius cogitari non potest, ut nec cogitari possit non esse. Et hoc es tu, domine deus noster. Sic ergo vere es, domine deus meus, ut nec cogitari possis non esse. Et merito. Si enim aliqua mens posset cogitare aliquid melius te, ascenderet creatura super creatorem, et iudicaret de creatore; quod valde est absurdum.' 
cumscribable, eternal, one, true good, powerful, knowledgeable, and volitional. For example, to prove that the divine substance is infinite, the Summa cites Proslogion, Chapter 22, where Anselm says that God has only a present existence and thus cannot be thought not to exist.

That goodness is called infinite from which comes every goodness and than which a greater cannot be thought; and likewise that power is called infinite from which comes every power and than which a greater cannot be thought. That, therefore, could be said to be infinite from which comes every existence and than which a greater cannot be thought; but such is divine existence, and therefore it is infinite. I say, moreover, that it exceedingly exists, as Anselm says that it differs from non-being exceedingly, namely that which has neither non-being after being nor being after non-being nor can be thought not to be. ${ }^{34}$

Since God has neither a past existence followed by non-existence nor a future existence preceded by non-existence, God's existence is infinite and thus the source of all finite existence.

The Summa also claims that the divine substance is both unmeasurable and uncircumscribable. To the objection given by the authors from John of Damascus, namely that only God is uncircumscribable, the authors offer a response inspired by the Proslogion, Chapter 13. Corporeal objects are completely circumscribed, since they are wholly in one place and not in another. Objects that are both circumscribed and uncircumscribed include created spirits, since they are circumscribed insofar as they cannot be everywhere, and yet they are partially uncircumscribed since they can exist in multiple places (e.g. such as distinct body parts in the case of human souls) simultaneously. Finally, only God is completely uncircumscribed since He is everywhere simultaneously. ${ }^{35}$

Chapter 20 of the Proslogion plays an important role in a discussion of the properties of divine eternity. Two important objections in one question seem to concede God's existence before created objects, ${ }^{36}$ but they find it difficult to distinguish between God's eternity and the perpetual existence of a creature that has no end. This difficulty is expressed well by Anselm himself, 'You fill and encompass all things; You are before and beyond all things. Indeed, You are before all things because before they were made You already are. But how is it that You are beyond

34 SH I, P1, In1, Tr2, Q1, C1 (n.34), p. 55: 'Item, bonitas illa dicitur infinita a qua est omnis bonitas et qua maior excogitari non potest et similiter illa potentia infinita a qua est omnis potentia et qua maior excogitari non potest; ergo et illud esse dicetur infinitum a quo est omne esse et quo maius excogitari non potest; sed tale est esse divinum; ergo illud est infinitum. Dico autem maxime esse, sicut dicit Anselmus, quod maxime distat a non esse, quod scilicet nec habet non esse post esse nec esse post non esse nec potest cogitari non esse.'

35 See $S H$ I, P1, In1, Tr2, Q3, Ti1, C2 (n. 39), p. 63.

36 See $S H$ I, P1, In1, Tr2, Q4, M2, C1 (n. 61), p. 89. 
all things? For how are You beyond those things which will have no end?'37 The Summa supplies Anselm's answer to these questions from later in the same chapter. Anselm gives three reasons why perpetual things cannot be equated with eternity even with respect to subsequent duration (ex parte post). ${ }^{38}$ The first is that creatures, even if they have a temporal beginning but no end, cannot exist without God; the second is that they can be thought of as not existing whereas God cannot be thought not to exist; and the third is that the eternity of God and the eternity of creatures are present to God, whereas creatures 'do not yet have that [part] of their eternity which is yet to come, even as they no longer have that [part] which is already past'. ${ }^{39}$

Anselm's Epistola de incarnatione verbi and his De processione spiritus sancti first become significant sources in the treatment on God's unity. To the objection that a unity without plurality is greater than a unity with plurality, the Summa responds that a distinction must be made between universal essence and the first essence. Universal essence is multiplied through the many things in which it exists; the first essence, however, while it exists in multiple things, that is, Persons, nonetheless is not multiplied through them. The Summa gives two highly abbreviated passages from Anselm, but this lengthier account from the end of De processione spiritus sancti articulates the point that the Summa is making:

[W] hen God is begotten from God or when God proceeds from God, the one who proceeds or is begotten does not pass outside of God but remains within God. So since God within God is only one God: when God is begotten from God, the one who begets and the one who is begotten are only one God; and when God proceeds from God, the one who proceeds and the one from whom He proceeds are only one God. Hence, since God has no parts but is wholly whatever He is, it follows inescapably that the Father is God as a whole, the Son is God as a whole, and the Holy Spirit is God as a whole-and they are one and the same God, not different gods. ${ }^{40}$

37 Anselm of Canterbury, Proslogion, c. 20 (Hopkins and Richardson, 106; Schmitt, 1:115): 'Tu ergo imples et complecteris omnia, tu es ante et ultra omnia. Et quidem ante omnia es, quia antequam fierent tu es. Ultra omnia vero quomodo es? Qualiter enim es ultra ea quae finem non habebunt?' 38 SH I, P1, In1, Tr2, Q4, M2, C1 (n. 61), p. 90: 'Anselmus, in Proslogion, assignans tres rationes quare perpetua non possunt aequari aeternitati etiam ex parte post.'

39 Anselm of Canterbury, Proslogion, c. 20 (Hopkins and Richardson, 106; Schmitt, 1:115-6): 'An hoc quoque modo transis omnia etiam aeterna, quia tua et illorum aeternitas tota tibi praesens est, cum illa nondum habeant de sua aeternitate quod venturum est, sicut iam non habent quod praeteritum est? Sic quippe semper es ultra illa, cum semper ibi sis praesens, seu cum illud semper sit tibi praesens, ad quod illa nondum pervenerunt,' and see SH I, P1, In1, Tr2, Q4, M2, C1 (n. 61), p. 90.

40 Anselm of Canterbury, De processione spiritus sancti, c. 16, in S. Anselmi cantuariensis archiepiscopi Opera omnia, 2:218-9 (Hopkins and Richardson, 513): 'Sed quoniam non est aliquid extra deum: cum nascitur deus de deo vel cum procedit deus de deo, non exit nascens vel procedens extra deum, sed manet in deo. Quoniam ergo deus in deo non est nisi unus deus: cum nascitur deus de deo, unus solus est deus gignens et genitus; et cum procedit deus de deo, unus tantummodo deus est procedens et de quo procedit. Unde inevitabiliter sequitur, quoniam deus nullas habet partes, sed totus est quidquid est: unum eundemque et non alium et alium deum totum esse patrem, totum esse filium, totum esse spiritum sanctum.' 
The Summa concedes that the principle affirming that a unity without plurality is greater than a unity with plurality is generally true-but only when it applies to creatures. ${ }^{41}$ Since divine unity is the highest unity that can 'exist or can be thought', it cannot be incompatible with a plurality of Persons who all remain 'within' God. ${ }^{42}$

Anselm's De veritate and Monologion return in a question about divine truth. Chapter 18 of the Monologion is the principal argument supporting the claim that truth must exist necessarily and thus eternally. If truth were not eternal, 'then even before truth had begun to be, it would have been true that there was no truth; and even after truth had come to an end, it would still be true that there would no longer be truth. ${ }^{43}$ The Summa glosses this passage by adding not only that truth must be eternal, but also, in Anselmian fashion, that it is not possible for one to think of it as not existing. ${ }^{44}$ The authors of the Summa also return to the distinction between speaking secundum quid and simpliciter that was used in the discussion on whether God can be thought not to exist. To the objection that truth secundum quid cannot prove a truth simpliciter because of an equivocation with respect to the word 'truth', the Summa insists that truth does exist eternally since the reduction of truth secundum quid to truth simpliciter does not imply that truth means the same thing in each case, but rather that if there is something true secundum quid, it must be reduced to something true simpliciter. ${ }^{45}$

In a question about divine goodness, Anselm functions as something of a foil to the position that the Summa maintains. The Summa argues, in a question about how to consider different kinds of goodness, that different kinds of goodness generally follow different kinds of being, but with one important distinction: goodness always implies a final cause. ${ }^{46}$ Anselm provides an argument about different kinds of truth that the authors of the Summa find useful as an objection. In De veritate, Anselm argues that there is only one rightness (rectitudo) that exists in any number of things, even if it seems at first that there must be one rightness for each right thing. For example, it might seem as though there is a rightness in each signification, in each thing signified, and in each will to signify; but Anselm argues that what gives any

41 See SH I, P1, In1, Tr3, Q1, M3, C2 (n. 83), p. 134.

42 SH I, P1, In1, Tr3, Q1, M3, C2 (n. 83), p. 134. 'Dicimus quod inter omnes unitates, quae possunt esse vel intelligi, unitas divina maior est et summa quae esse vel intelligi possit; nec est dicendum quod ei repugnat pluralitas personarum et notionum.'

43 Anselm of Canterbury, Monologion, c. 18 (Hopkins and Richardson, 30; Schmitt, 1:33): 'Quodsi neutrum horum cogitari potest, et utrumque hoc verum sine veritate esse non potest: impossibile est vel cogitare, quod veritas principium aut finem habeat. Denique si veritas habuit principium vel habebit finem: antequam ipsa inciperet, verum erat tunc quia non erat veritas; et postquam finita erit, verum erit tunc quia non erit veritas. Atqui verum non potest esse sine veritate. Erat igitur veritas, antequam esset veritas; et erit veritas, postquam finita erit veritas; quod inconvenientissimum est.' 44 See SH I, P1, In1, Tr3, Q2, M1, C1 (n. 87), p. 138.

45 See SH I, P1, In1, Tr3, Q2, M1, C1 (n. 87), p. 139.

46 See SH I, P1, In1, Tr3, Q3, M1, C3 (n. 106), p. 168. 
one of these things its rightness is a rectitudo that exists eternally. ${ }^{47}$ The objection that is formulated from this argument is that just as truth is not multiplied according to different kinds of being, but rather according to things, signs, and intentions, among others, so too goodness cannot be multiplied according to different kinds of being. Setting aside the fact that the Summa actually tends to follow the student's line of reasoning in Anselm's dialogue less than the teacher's, which represents better Anselm's own position and setting aside the fact that Anselm is not discussing goodness in the passage from De veritate, one can note that while Anselm emphasizes the one rectitudo in all things, the Summa permits the distinction between absolute and uncreated goodness on the one hand and relative and created goodness on the other. The Summa and Anselm agree that goodness is not multiplied according to different kinds of being, ${ }^{48}$ but not for the same reasons. Anselm emphasizes that truth (and the Summa infers goodness, as well) exists independently of any true thing, while the Summa argues that goodness can refer either to an end or something as ordered to an end. In the former case, God is good per essentiam, while creatures are good per participationem. ${ }^{49}$

Anselm's Cur Deus homo makes an appearance in the Summa's discussion of God's power. After treating God's absolute power, the Summa asks questions about the relation among God's power, knowledge, and will with respect to creatures. The Summa, in its literary structure, treats these three aspects in that order, namely, power, knowledge, and will; and yet, Anselm clearly states in Cur Deus homo that ability depends on willing. One finds this assertion in Cur Deus homo, Book 2, Chapter 10, in a discussion about Christ's ability to sin. The literary figure Anselm addresses Boso's concern that Jesus says to the Jewish leaders in John 8:55, 'If I said, I do not know him, I should be a liar like you; but I do know him and I keep his word.' Boso seems to think that Jesus' statement implies that He could lie if He wanted to do so. Anselm provides the following response:

All ability depends upon willing. For when I say "I am able to speak or to walk", the proviso "if I will to" is understood. For if willing is not included, then the ability is not really an ability but is a necessity. For when I say "I am able to be dragged off or to be overcome against my will", this is not an instance of my ability but is an instance of constraint and of another's ability. Indeed, "I am able to be dragged off or to be overcome" means nothing other than "Someone else is able to drag me off or to overcome me.” Therefore, we can say of Christ, "He was able to tell a lie”, provided "if He willed to" is understood. And since He was not able to lie against His will and was not able to will to lie, He can equally well be said not to have been able to lie. So, then, He was able to lie and not able to lie. ${ }^{50}$

47 See Anselm of Canterbury, De veritate, c. 13 (Schmitt, 1:196-9).

48 See SH I, P1, In1, Tr3, Q3, M1, C3 (n. 106), p. 168.

49 See SH I, P1, In1, Tr3, Q3, M1, C3 (n. 106), p. 168.

50 Anselm of Canterbury, Cur Deus homo II, c. 10, in S. Anselmi cantuariensis archiepiscopi Opera omnia, 2:107 (Hopkins and Richardson, 360): 'Omnis potestas sequitur voluntatem. Cum enim dico quia possum loqui vel ambulare, subauditur: si volo. Si enim non subintelligitur voluntas, non est potestas sed necessitas. Nam cum dico quia nolens possum trahi aut vinci, non est haec mea potes- 
The Summa focuses on the statement that 'ability depends upon willing', but it makes a distinction that allows the authors to reconcile Anselm's statement with their own position. This distinction is between power in habitu and power in effectu (or potentia potens and potentia exequens). With power in habitu power is conceived before the will; and with power in effectu, the will is conceived before power. ${ }^{51}$ The Summa contends that willing derives from ability 'according to our method of understanding; nevertheless, in God they are the same'. Because 'the execution of power in act is from the will', one could say that 'ability depends upon willing', but properly speaking, that is not the case. ${ }^{52}$ Thus, Anselm's contention that 'ability depends upon willing' is true insofar as it means that when God wills to do something, such as create or redeem, He is able to do so because He has willed it; and yet, God could not will in the first place if He did not have the power to do so.

Anselm's De concordia praescentiae et praedestinationis plays an important role in the Summa's discussions of God's knowledge and foreknowledge. Regarding the question about whether God's foreknowledge causes things, the Summa marshals Anselm's explanation of God's foreknowledge in De concordia. There Anselm says,

Therefore, when I say "If God foreknows something, it is necessary that this thing (...) occur", it is as if I were to say: "If this thing will occur, of necessity it will occur." But this necessity neither compels nor prevents a thing's existence or non-existence. For because the thing is presumed to exist, it is said to exist of necessity; or because it is presumed not to exist, it is said to not-exist of necessity. ${ }^{53}$

Drawing on this statement, the Summa makes a distinction between knowledge of simple intelligence (scientia simplices notitiae) and knowledge of approval (scientia approbationis). God's knowledge of simple intelligence is not causal in any way, since it is mere knowledge with no approval (or disapproval) brought to bear on it; the knowledge of approval, however, does imply a cause since in addition to

tas, sed necessitas et potestas alterius. Quippe non est aliud: possum trahi vel vinci, quam: alius me trahere vel vincere potest. Possumus itaque dicere de Christo quia potuit mentiri, si subauditur: si vellet. Et quoniam mentiri non potuit nolens nec potuit velle mentiri, non minus dici potest nequivisse mentiri. Sic itaque potuit et non potuit mentiri.'

51 See SH I, P1, In1, Tr4, Q1, M2, C2 (n. 135), p. 207.

52 SH I, P1, In1, Tr4, Q1, M2, C2 (n. 135), p. 207: 'Ad auctoritates ergo obiectas intelligendum quod per illas non significatur quod potentia sit subiecta voluntati aut sequatur eam secundum se, cum velle sit ex posse, secundum rationem intelligentiae tamen in Deo sunt idem, sed quia executio potentiae in actum est a voluntate; ratione ergo eius in quod est potentia, dicitur potentia sequi voluntatem, non ratione sui.'

53 Anselm of Canterbury, De concordia praescentiae et praedestinationis, 1.2, in S. Anselmi cantuariensis archiepiscopi Opera omnia, 2:248-9 (Hopkins and Richardson, 533): 'Quare cum dico quia si praescit deus aliquid, necesse est illud esse futurum: idem est ac si dicam: Si erit, ex necessitate erit. Sed haec necessitas nec cogit nec prohibet aliquid esse aut non esse. Ideo enim quia ponitur res esse, dicitur ex necessitate esse; aut quia ponitur non esse, affirmatur non esse ex necessitate.' 
knowledge, there is an accompanying approbatio intellectae. ${ }^{54}$ When the Summa asks further questions about whether foreknowledge may be caused by things, whether foreknowledge imposes necessity on anything, and whether foreknowledge and free choice are compatible, the opening chapters of De concordia are invoked to assert four things regarding God's foreknowledge: 1 . it causes good; 2 . it does not cause evil; 3. it is not caused by finite creatures; and 4. it is compatible with human freedom.

The will is the last aspect of the divine substance that the Summa treats with Anselm's influence. The Summa addresses the question of whether God can command something that contradicts the natural law. Anselm contends in Cur Deus homo that 'what God wills is just and what He does not will is not just', ${ }^{55}$ so it seems that God could command something that contradicts the natural law. Although the Summa fails to quote the remainder of Anselm's passage, it is worth quoting in full here, since it likely helped the authors formulate their response to the contrary:

[W]e must not interpret this to mean that if God were to will any kind of unfittingness, it would be just simply because He willed it. For the supposition "God wills to lie" does not warrant the inference "Lying is just", but, instead, warrants the inference "This being is not really God". For no will can at all will to lie except a will in which the truth has been corrupted-or better, a will which has become corrupted by abandoning the truth. Therefore, when we say "If God wills to lie", this means "If God is of such a nature as to will to lie. ( ... )" And so, "Lying is just" is not inferable therefrom-unless we interpret the if-then statement as an example of our saying about two impossibilities "If this is true, then that is true", although neither the one nor the other is true. $^{56}$

Anselm qualifies the statement that 'what God wills is just and what He does not will is not just' by saying that God's incorrupt will could not will to lie, since a will to lie would have been corrupted 'abandoning the truth'.

With that qualification in mind the Summa distinguishes between three different ways of being 'against nature'. The first is against the human experience of nature (consuetudinem naturae); the second is against the order and potency implanted by God in the natural universe; and the third is against the law of the highest na-

54 See SH I, P1, In1, Tr5, S2, Q1, C2 (n. 182), p. 268.

55 Anselm of Canterbury, Cur Deus homo I, c. 12 (Hopkins and Richardson, 321; Schmitt, 2:107): 'Quod autem dicitur quia quod vult iustum est, et quod non vult non est iustum.'

56 Anselm of Canterbury, Cur Deus homo I, c. 12 (Hopkins and Richardson, 321; Schmitt, 2:107): '[N]on ita intelligendum est ut, si deus velit quodlibet inconveniens, iustum sit, quia ipse vult. Non enim sequitur: si deus vult mentiri, iustum esse mentiri; sed potius deum illum non esse. Nam nequaquam potest velle mentiri voluntas, nisi in qua corrupta est veritas, immo quae deserendo veritatem corrupta est. Cum ergo dicitur: si deus vult mentiri non est aliud quam: si deus est talis natura quae velit mentiri; et idcirco non sequitur iustum esse mendacium. Nisi ita intelligatur, sicut cum de duobus impossibilibus dicimus: si hoc est, illud est; quia nec hoc nec illud est.' 
ture. ${ }^{57}$ Since the law of the highest nature regulates all things, God cannot prescribe against the natural law in that sense. He can command, however, an act that contradicts the usual order implanted by God in nature. ${ }^{58}$

From this conclusion, the Summa argues that, while God cannot will anything unfitting, He could order something that seems to be against the Second Table of the Decalogue, as long as it did not prevent the person or community from achieving their final end, namely God Himself. On the one hand the Summa argues that God cannot command something that violates the Decalogue, and on the other, he can command actions that preserve the human tendency toward God while altering their relations with each other. The authors of the Summa clearly have in mind God's command to Abraham to kill Isaac, the despoliation of the Egyptians by the Israelites, and patriarchal polygamy. God is free to command any action that preserves the human order towards God, as long as it does not involve injustice. Thus, when Anselm says that 'there is freedom only with respect to what is advantageous or what is fitting', the authors of the Summa infer from that statement that He cannot command evil; but He could command something that preserves justice and charity while altering the relations among humans. As examples, the Summa contends that God could order the despoliation of the Egyptians while still prohibiting theft, and He could command concubinage or sexual intercourse while still prohibiting fornication. What would be preserved in such commands is the prohibition of cupidity and lust, while taking something from someone or having intercourse with a concubine could be done justly. ${ }^{59}$

Another facet of the will in which Anselm's thought plays a role pertains to God's mercy and justice. Following the Proslogion, Chapter 8, the Summa contends that God is merciful and just, not in the sense that He feels sorrow or owes anything to anyone, but in the sense that He relieves peoples' suffering or pardons their sins. ${ }^{60}$ It also means that God's mercy and justice, while not being directed towards creatures from all eternity, nonetheless can be found in His works. ${ }^{61}$

\section{Conclusion}

Anselm's influence on the Summa's theology of the divine substance is much greater than can be recounted here. Although many of the approximately 175 references to

57 See SH I, P1, In1, Tr6, Q3, Ti2, M2, C1, Ar2 (n. 275), p. 380. This account summarizes Augustine's Contra Faustum 26.3, ed. Josef Zycha, Corpus Scriptorum Ecclesiasticorum Latinorum, 25/1 (Vienna: Tempsky, 1891), 730-1.

58 See $S H$ I, P1, In1, Tr6, Q3, Ti2, M2, C1, Ar2 (n. 275), p. 380.

59 See $S H$ I, P1, In1, Tr6, Q3, Ti2, M2, C1, Ar3 (n. 276), p. 383.

60 See $S H$ I, P1, In1, Tr6, Q3, Ti2, M2, C3, Ar1 (n. 280), p. 388. See also SH I, P1, In1, Tr6, Q3, Ti2, M2, C3, Ar2 (n. 281), pp. 389-90.

61 See SH I, P1, In1, Tr6, Q3, Ti2, M2, C3, Ar3 (n. 282), pp. 390-8. 
Anselm in Book 1 of the Summa deal with topics other than the existence and attributes of the divine substance (e.g. the Trinitarian Persons and divine names), nonetheless, when one considers that there are over 40 references to the Monologion and over 30 each to the Proslogion and De veritate, one can see that there is a significant expansion in the engagement with and appropriation of Anselmian texts and arguments compared with the previous generation of theological texts. In the 1220s, the primary engagement with Anselm consisted principally with Anselm's contention in Chapter 3 of the Proslogion that God cannot be thought not to exist, and Anselm's discussions about God's attributes are neglected. Only William of Auxerre, whose Summa aurea proved to be a significant influence on the Summa Halensis, used a variety of Anselmian passages to discuss multiple divine attributes. Nonetheless, William's engagement with Anselm is far less than that of the Summa Halensis.

Part of the reason for increased sustained engagement with Anselm can be found simply in the increased scope of the Summa and the vast multiplication of questions compared to the theological texts from the 1220s. Nonetheless, the authors of the Summa could have chosen other interlocutors as they formulated their questions. Anselm's inclusion in questions not only regarding God's existence, but also regarding God's truth, goodness, power, knowledge, and will suggests at the very least an increased engagement with and appreciation of the full range of Anselm's philosophical and theological works. Whereas William of Auxerre had drawn principally from the Proslogion, the Monologion, and De veritate, the Summa Halensis found other works useful, as well, including the Cur Deus homo (even in questions about the divine substance), De concordia praescientiae et praedestinationis et gratiae dei cum libero arbitrio, and De processione spiritus sancti (especially in questions about God's unity). Drawing from a wide array of Anselmian texts, some of which were quoted at much greater length than any such passages in the theology manuals of the 1220s, the authors of the Summa appropriated Anselm as a theological authority whose arguments aided them in formulating their own teachings on the divine substance. 
